\title{
Genotyping of Serratia marcescens Strains Associated with Cucurbit Yellow Vine Disease by Repetitive Elements- Based Polymerase Chain Reaction and DNA-DNA Hybridization
}

\author{
Q. Zhang, R. Weyant, A. G. Steigerwalt, L. A. White, U. Melcher, \\ B. D. Bruton, S. D. Pair, F. L. Mitchell, and J. Fletcher
}

\begin{abstract}
First and ninth authors: Department of Entomology and Plant Pathology, Oklahoma State University, Stillwater 74078; second, third, and fourth authors: Centers for Disease Control and Prevention, Atlanta, GA 30333; fifth author: Department of Biochemistry and Molecular Biology, Oklahoma State University, Stillwater; sixth and seventh authors: U.S. Department of Agriculture-Agriculture Research Service, Lane, OK 74555; and eighth author: Texas Agricultural Experiment Station, Stephenville 76401.
\end{abstract}

Accepted for publication 23 April 2003.

\begin{abstract}
Zhang, Q., Weyant, R., Steigerwalt, A. G., White, L. A., Melcher, U., Bruton, B. D., Pair, S. D., Mitchell, F. L., and Fletcher, J. 2003. Genotyping of Serratia marcescens strains associated with cucurbit yellow vine disease by repetitive elements-based polymerase chain reaction and DNA-DNA hybridization. Phytopathology 93:1240-1246.

The bacterium that causes cucurbit yellow vine disease (CYVD) has been placed in the species Serratia marcescens based on 16S rDNA and groE sequence analysis. However, phenotypic comparison of the organism with $S$. marcescens strains isolated from a variety of ecological niches showed significant heterogeneity. In this study, we compared the genomic DNA of $S$. marcescens strains from different niches as well as type strains of other Serratia spp. through repetitive elements-based polymerase chain reaction (rep-PCR) and DNA-DNA hybridization. With the former, CYVD strains showed identical banding patterns despite the

fact that they were from different cucurbit hosts, geographic locations, and years of isolation. In the phylogenetic trees generated from rep-PCR banding patterns, CYVD strains clearly were differentiated from other strains but formed a loosely related group with $S$. marcescens strains from other niches. The homogeneity of CYVD strains was supported further by the DNA relatedness study, in that labeled DNA from the cantaloupe isolate, C01-A, showed an average relative binding ratio (RBR) of $99 \%$, and $0.33 \%$ divergence to other CYVD strains. Used as a representative strain of CYVD, the labeled C01-A had a RBR of $76 \%$, and a $4.5 \%$ divergence to the $S$. marcescens type strain. These data confirm the previous placement of CYVD strains in S. marcescens. Our investigations, including rep-PCR, DNA-DNA hybridization, and previous phenotyping experiments, have demonstrated that CYVD-associated strains of $S$. marcescens cluster together in a group significantly different from other strains of the species.
\end{abstract}

Cucurbit yellow vine disease (CYVD) was first observed in squash (Cucurbita maxima) and pumpkin (C. pepo) in 1988 in Oklahoma and Texas (7), but is now known to affect other cucurbits, including watermelon and cantaloupe. The disease has been confirmed in Arkansas (J. C. Correll, personal communication), Tennessee (4), Massachusetts (26), Kansas (N. A. Tisserat, J. Fletcher, and B. D. Bruton, unpublished data), Colorado (B. D. Bruton, unpublished data), and Nebraska (R. M. Harveson and B. D. Bruton, unpublished data). Affected plants exhibit characteristic symptoms of yellowing, stunting, gradual decline, and phloem discoloration. Losses can range from less than 5 to $100 \%$ in affected fields.

Disease symptoms consistently are associated with the presence in the phloem of a rod-shaped, gram-negative bacterium, detected using transmission electron microscopy (7). The bacterium was cultured, and Koch's postulates were completed by mechanical inoculations and by transmission via an insect vector, the squash bug, Anasa tristis, confirming that this bacterium is the causal agent of CYVD (6).

Two CYVD pathogenic strains, W01-A and Z01-A, were originally isolated from diseased watermelon and zucchini, respectively. Sequence analysis of $16 \mathrm{~S}$ rDNA and groE gene fragments of these two strains indicated that they shared more than

Corresponding author: J. Fletcher; E-mail address: jaf2394@ okstate.edu.

Publication no. P-2003-0725-02R

(c) 2003 The American Phytopathological Society
97\% sequence similarity with the type strain of Serratia marcescens (19). The possible identity of the CYVD bacterium as $S$. marcescens was unexpected. Different strains of this species can assume roles as soil saprophytes (17), plant endophytes (24), insect pathogens (8), and even opportunistic human pathogens (25), but the only previous reports of plant pathogenicity for this species, in sainfoin (21) and alfalfa (13), were made when the tools of bacterial identification were less definitive than those of today.

Biological characterization of Z01-A and W01-A using BIOLOG and fatty acid profiling showed that, despite the strong similarity of their $16 \mathrm{~S}$ rDNA and groE genes to those of other $S$. marcescens, CYVD strains were quite unique in some other respects, lacking a number of metabolic functions and possessing different lipid complements than those present in $S$. marcescens strains from other niches (19).

This apparent disparity led us to seek a more definitive confirmation of the identity of CYVD strains and to examine the taxonomic position of the CYVD bacteria based on techniques that take into consideration the sequence and organization of the entire chromosome. In addition, the broad geographic distribution and potential devastation of this disease make it important to better understand the genetic relationships among CYVD strains, because these may provide clues as to their site of origin, pattern of spread, and disease epidemiology.

Repetitive elements-based polymerase chain reaction (rep-PCR) generates DNA fingerprints by amplifying different-sized DNA fragments lying between the repetitive elements in a genome. The amount of differentiation among the tested strains depends on the 
primer used; however, overall, the rep-PCR banding patterns of strains from the same bacterial species can be quite diverse and often reveal relationships not seen by other methods. This method has been used successfully to fingerprint clinical isolates of $S$. marcescens (18). DNA-DNA hybridization, on the other hand, has the advantage of comparing organisms at the whole-chromosome level. The goals of this work were to type CYVD strains, based on repetitive elements, and to determine the DNA relatedness among CYVD strains as well as between plant-pathogenic strains and those from other niches.

\section{MATERIALS AND METHODS}

Bacterial isolates and growth conditions. Tested bacteria included type strains of several Serratia spp., several S. marcescens strains from different ecological niches, and several CYVD isolates from different cucurbit hosts, geographical locations, and years of isolation (Table 1). Bacteria were stored at $-80^{\circ} \mathrm{C}$ in aliquots in $1.5 \mathrm{ml}$ of Luria-Bertani (LB) broth containing $15 \%$ glycerol. For use in experiments, bacteria were streaked onto LB agar (20) and incubated at $28^{\circ} \mathrm{C}$ for $24 \mathrm{~h}$.

TABLE 1. Strains of cucurbit yellow vine disease-associated and nonassociated Serratia marcescens and other Serratia spp. used in this study

\begin{tabular}{|c|c|c|c|c|c|c|}
\hline $\begin{array}{l}\text { Strain } \\
\text { designation }\end{array}$ & Alternative & Host & Location & Collection date & rep-PCR & DNA-DNA hybridization \\
\hline \multicolumn{7}{|l|}{ CYVD strains ${ }^{b}$} \\
\hline W01-A to W01-J & $\ldots$ & Watermelon & Texas & 1999 & $\mathrm{Y}$ & $\mathrm{Y}$ \\
\hline W04-A & $\ldots$ & Watermelon & Arkansas & 2000 & $\mathrm{Y}$ & ND \\
\hline W05-A & $\ldots$ & Watermelon & Arkansas & 2001 & $\mathrm{Y}$ & $\mathrm{Y}$ \\
\hline W08-A & $\ldots$ & Watermelon & Oklahoma & 1997 & $\mathrm{Y}$ & Y \\
\hline W09-A & $\ldots$ & Watermelon & Oklahoma & 1997 & $\mathrm{Y}$ & Y \\
\hline Z01-A & $\ldots$ & Zucchini & Oklahoma & 1999 & $\mathrm{Y}$ & $\mathrm{Y}$ \\
\hline Z01-B & $\ldots$ & Zucchini & Oklahoma & 1999 & $\mathrm{Y}$ & ND \\
\hline Z02-A & $\ldots$ & Zucchini & Oklahoma & 1999 & $\mathrm{Y}$ & ND \\
\hline Z02-B & $\ldots$ & Zucchini & Oklahoma & 1999 & $\mathrm{Y}$ & $\mathrm{Y}$ \\
\hline P01-A & $\ldots$ & Pumpkin & Oklahoma & 1999 & $\mathrm{Y}$ & $\mathrm{Y}$ \\
\hline P01-B & $\ldots$ & Pumpkin & Oklahoma & 1999 & Y & ND \\
\hline P02-A & $\ldots$ & Pumpkin & Oklahoma & 1999 & $\mathrm{Y}$ & Y \\
\hline P02-B & $\ldots$ & Pumpkin & Oklahoma & 1999 & $\mathrm{Y}$ & ND \\
\hline P03-A & $99-2515$ & Pumpkin & Oklahoma & 2000 & $\mathrm{Y}$ & ND \\
\hline P07-A & 00B058 & Pumpkin & Massachusetts & 2001 & $\mathrm{Y}$ & ND \\
\hline P08-A & 00B060 & Pumpkin & Massachusetts & 2001 & $\mathrm{Y}$ & Y \\
\hline C01-A & $\ldots$ & Cantaloupe & Oklahoma & 1999 & $\mathrm{Y}$ & Y \\
\hline C01-B & $\ldots$ & Cantaloupe & Oklahoma & 1999 & $\mathrm{Y}$ & ND \\
\hline $\mathrm{C} 02-\mathrm{A}$ & $\ldots$ & Cantaloupe & Oklahoma & 1999 & $\mathrm{Y}$ & $\mathrm{Y}$ \\
\hline $\mathrm{C} 02-\mathrm{B}$ & $\ldots$ & Cantaloupe & Oklahoma & 1999 & $\mathrm{Y}$ & ND \\
\hline \multicolumn{7}{|l|}{ Endophytic strains } \\
\hline $\mathrm{R} 01-\mathrm{A}^{\mathrm{c}}$ & IRBG 501 & Rice & Philippines & Unknown & Y & Y \\
\hline $\mathrm{R} 02-\mathrm{A}^{\mathrm{c}}$ & IRBG 502 & Rice & Philippines & Unknown & $\mathrm{Y}$ & $\mathrm{Y}$ \\
\hline $\mathrm{R} 03-\mathrm{A}^{\mathrm{c}}$ & IRBG 505 & Rice & Philippines & Unknown & $\mathrm{Y}$ & ND \\
\hline G01 ${ }^{\mathrm{d}}$ & $90-166$ & Cotton & Alabama & Unknown & $\mathrm{Y}$ & $\mathrm{Y}$ \\
\hline $\mathrm{G} 02^{\mathrm{d}}$ & JM-965 & Cotton & Unknown & Unknown & $\mathrm{Y}$ & Y \\
\hline $\mathrm{G}^{0} 3^{\mathrm{d}}$ & JM-983 & Cotton & Unknown & Unknown & $\mathrm{Y}$ & $\mathrm{Y}$ \\
\hline \multicolumn{7}{|c|}{ Animal pathogenic strains } \\
\hline $\mathrm{I} 02-\mathrm{A}^{\mathrm{e}^{\mathrm{t}}}$ & $0-8-12$ & Insect & California & 1961 & $\mathrm{Y}$ & ND \\
\hline I06- $\mathrm{A}^{\mathrm{e}}$ & $56-1-1$ & Insect & California & 1960 & $\mathrm{Y}$ & ND \\
\hline $\mathrm{I} 09-\mathrm{A}^{\mathrm{e}}$ & $73-1-1$ & Insect & California & 1961 & $\mathrm{Y}$ & ND \\
\hline $\mathrm{H} 01-\mathrm{A}^{\mathrm{f}}$ & $\ldots$ & Human & Oklahoma & 1999 & $\mathrm{Y}$ & $\mathrm{Y}$ \\
\hline $\mathrm{H} 02-\mathrm{A}^{\mathrm{f}}$ & $\ldots$ & Human & Oklahoma & 1999 & $\mathrm{Y}$ & Y \\
\hline V01-A ${ }^{f}$ & 94100675 & Feline & Oklahoma & Unknown & $\mathrm{Y}$ & ND \\
\hline \multicolumn{7}{|l|}{ Saprophytic strains } \\
\hline $\mathrm{S} 01-\mathrm{A}^{\mathrm{d}}$ & CP01(4)CU & Rhizosphere & Unknown & Unknown & $\mathrm{Y}$ & $\mathrm{Y}$ \\
\hline S02-A ${ }^{d}$ & $98 \mathrm{~A}-742$ & Soil & Florida & Unknown & $\mathrm{Y}$ & $\mathrm{Y}$ \\
\hline $\mathrm{S} 03-\mathrm{A}^{\mathrm{g}}$ & ROX6 & Soil & Oklahoma & 2001 & $\mathrm{Y}$ & ND \\
\hline \multicolumn{7}{|l|}{ Serratia spp. } \\
\hline S. fonticola ${ }^{\mathrm{h}}$ & $\ldots$ & Spring water & ATCC 29844 & Unknown & $\mathrm{Y}$ & $\mathrm{Y}$ \\
\hline S. grimesii $^{\mathrm{h}}$ & $\ldots$ & Unknown & ATCC 14460 & Unknown & $\mathrm{Y}$ & $\mathrm{Y}$ \\
\hline S. liquefaciens ${ }^{\mathrm{h}}$ & $\ldots$ & Milk & ATCC 27592 & Unknown & $\mathrm{Y}$ & $\mathrm{Y}$ \\
\hline S. marcescens ${ }^{\mathrm{h}}$ & $\ldots$ & Water & ATCC 13880 & Unknown & $\mathrm{Y}$ & $\mathrm{Y}$ \\
\hline S. plymuthica ${ }^{\mathrm{h}}$ & $\ldots$ & Water & ATCC 183 & Unknown & $\mathrm{Y}$ & $\mathrm{Y}$ \\
\hline S. rubidaea ${ }^{\mathrm{h}}$ & $\ldots$ & Unknown & ATCC 27593 & Unknown & $\mathrm{Y}$ & $\mathrm{Y}$ \\
\hline S. ficaria $^{\mathrm{h}}$ & $\ldots$ & Unknown & ATCC 33105 & Unknown & ND & $\mathrm{Y}$ \\
\hline S. proteamaculans ${ }^{\mathrm{h}}$ & $\ldots$ & Unknown & ATCC 19323 & Unknown & ND & $\mathrm{Y}$ \\
\hline S. odorifera ${ }^{\mathrm{h}}$ & $\ldots$ & Unknown & ATCC 33077 & Unknown & ND & $\mathrm{Y}$ \\
\hline
\end{tabular}

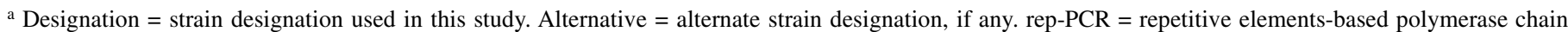
reaction. $\mathrm{Y}=$ test performed and $\mathrm{ND}=$ not done.

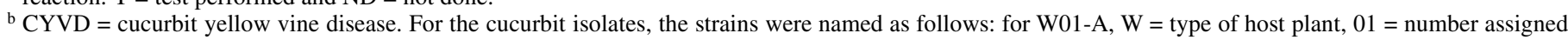
to the plant from which the strain was isolated, and A = number assigned to one particular strain isolated from that plant. W01-A to W01-J represents 10 isolates; all other lines list only single isolates. Strains isolated from the same host, state, and year were from the same field.

c Provided by J. K. Ladha, International Rice Research Institute, Los Banos, Philippines.

d Provided by J. Kloepper, University of Alabama, Auburn.

e Provided by A. H. Purcell, University of California, Berkeley.

${ }^{f}$ Provided by D. Adamson, Medical Arts Laboratory, Oklahoma City, OK.

g Provided by S. P. Deng, Oklahoma State University, Stillwater.

${ }^{\mathrm{h}}$ Provided by the American Type Culture Collection, Manassas, VA. All the strains listed are the type strain of the respective species. 
DNA isolation. Single colonies were transferred to $5 \mathrm{ml}$ of $\mathrm{LB}$ broth and incubated at $28^{\circ} \mathrm{C}$, with shaking at $220 \mathrm{rpm}$, for $18 \mathrm{~h}$. DNA was extracted using a modified version of the hexadecyl trimethyl ammonium bromide (CTAB) method (2). Briefly, $5 \mathrm{ml}$ of bacterial culture were centrifuged for $5 \mathrm{~min}$ at $10,000 \times g$ and $4^{\circ} \mathrm{C}$, the supernatant was removed, and the pellet was resuspended in $200 \mu$ of TE buffer (10 mM Tris-HCl, $1 \mathrm{mM}$ EDTA, pH 8.0). The mixture was incubated $30 \mathrm{~min}$ at $60^{\circ} \mathrm{C}$, then $100 \mu \mathrm{l}$ of $5 \mathrm{M}$

A

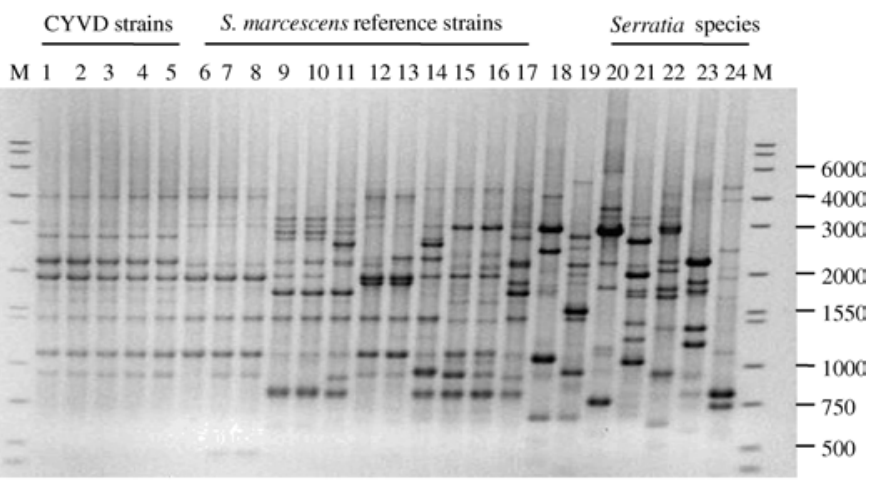

B

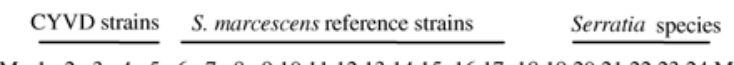

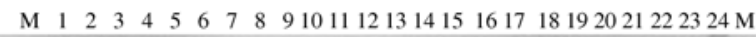

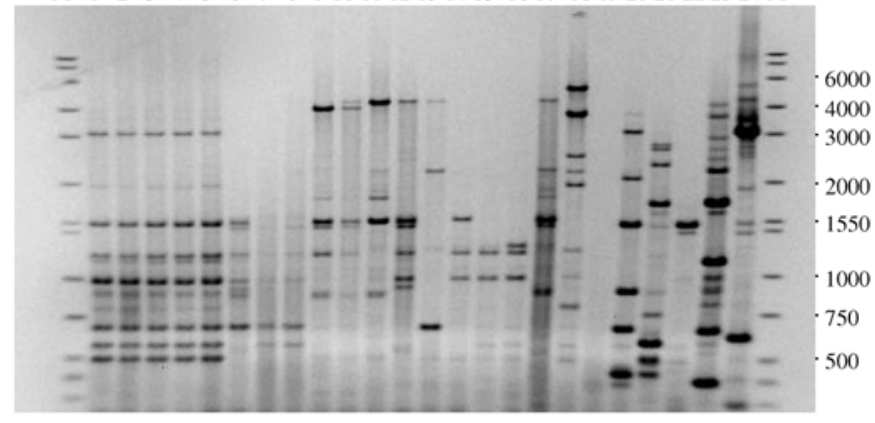

C

$\underline{\text { CYVD strains }} \quad$ S. marcescens reference strains $\quad$ Serratia species

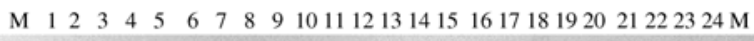

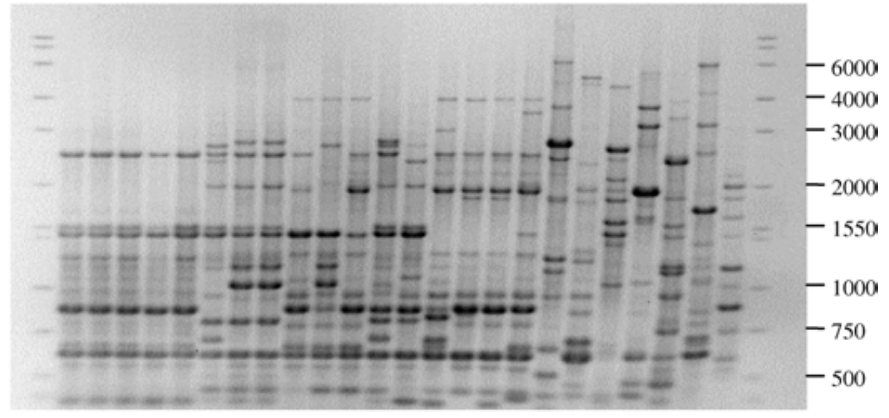

Fig. 1. Agarose electrophoresis gels of repetitive elements-based polymerase chain reaction (rep-PCR) products generated from cucurbit yellow vine disease (CYVD) strains, Serratia marcescens from various niches, and other Serratia type strains. A, Polymorphic GC-rich repetitive sequences primer, $\mathbf{B}$, enterobacterial repetitive intergenic consensus (ERIC) primers, and $\mathbf{C}$, BOX primer. Lanes labeled $M$ were run with the DNA ladder (DirectLoad; Sigma-Aldrich, St. Louis), sizes of fragments are listed on the right. Lane 1, C01-A; lane 2, P01-A; lane 3, W01-A; lane 4, Z01-A; lane 5, P03-A; lane 6, R01-A; lane 7, R02-A; lane 8, R03-A; lane 9, S01-A; lane 10, S02-A; lane 11, H01-A; lane 12, H02-A; lane 13, G01-A; lane 14, V01-A; lane 15, I06-A; lane 16, I09-A; lane 17, S. marcescens; lane 18, G02-A; lane 19, G03-A; lane 20, S. grimesii; lane 21, S. plymuthica; lane 22, S. rubideae; lane 23, S. liquefaciens; and lane 24, S. fonticola.
$\mathrm{NaCl}$ and $80 \mu \mathrm{l}$ of CTAB solution $(10 \%$ CTAB in $0.7 \mathrm{M} \mathrm{NaCl})$ were added and mixed, and the suspension was incubated at $60^{\circ} \mathrm{C}$ for $10 \mathrm{~min}$. The solution was extracted with an equal volume of phenol/chloroform/isoamyl alcohol (25:24:1). The aqueous phase was mixed with 0.6 vol of isopropanol, and DNA precipitated at $-20^{\circ} \mathrm{C}$ for at least $15 \mathrm{~min}$. DNA was collected by centrifugation $\left(20,000 \times g\right.$ for $15 \mathrm{~min}$ at $\left.4^{\circ} \mathrm{C}\right)$ and washed with $70 \%$ ethanol. The DNA pellet was air dried at room temperature for $15 \mathrm{~min}$, and then dissolved in $100 \mu \mathrm{l}$ of TE buffer ( $\mathrm{pH}$ 8.0). The DNA solution was stored at $-20^{\circ} \mathrm{C}$ until use.

Rep-PCR. The BOX primer (14), polymorphic GC-rich repetitive sequences (PGRS) primer (18), and enterobacterial repetitive intergenic consensus (ERIC) primers (11) were synthesized by the Oklahoma State University Recombinant DNA-Protein Resource Facility. Amplification was performed with each of three primer sets: BOX/BOX, PGRS/PGRS, and ERIC1R/ERIC2. Each reaction consisted of $5 \mu \mathrm{l}$ of $1 \times$ Gitshier buffer $(16.6 \mathrm{mM}$ $\left[\mathrm{NH}_{4}\right]_{2} \mathrm{SO}_{4} ; 67 \mathrm{mM} \mathrm{HCl}, \mathrm{pH} 8.8 ; 6.7 \mathrm{mM} \mathrm{MgCl}$; 6.7 mM EDTA; and $30 \mathrm{mM} \beta$-mercaptoethanol), 10\% bovine serum albumin, $10 \%$ dimethyl sulfoxide (vol/vol; Fluka Chemical Corp., Ronkonkoma, NY), 50 pmoles of primer, $125 \mathrm{mM}$ each dNTP, 2 units of Taq polymerase (Promega Corp., Madison, WI), and $1 \mu \mathrm{l}$ of the bacterial DNA solution. The total volume per reaction was $25 \mu \mathrm{l}$. Amplification was carried out in a DNA thermal cycler 480 (PerkinElmer Cetus, Norwalk, CT). Reaction conditions were slightly modified from previous studies (18). With all three primer sets, each round of amplification began with initial incubation at $94^{\circ} \mathrm{C}$ (3 s) and $92^{\circ} \mathrm{C}(30 \mathrm{~s})$. This was followed by $52^{\circ} \mathrm{C}(1 \mathrm{~min})$ and $65^{\circ} \mathrm{C}(8 \mathrm{~min})$ for the $\mathrm{BOX}$ primer, $50^{\circ} \mathrm{C}(1 \mathrm{~min})$ and $65^{\circ} \mathrm{C}(8 \mathrm{~min})$ for the ERIC primers, or $54^{\circ} \mathrm{C}(1 \mathrm{~min})$ and $72^{\circ} \mathrm{C}(8 \mathrm{~min})$ for the PGRS primers. A total of 35 cycles was used. An 8- $\mu$ l aliquot of the PCR product was analyzed on a $1.5 \%$ agarose gel, electrophoresed at $70 \mathrm{~V}(4 \mathrm{~V} / \mathrm{cm})$ for $5 \mathrm{~h}$ in $1 \times$ Tris-acetate EDTA buffer ( $\mathrm{pH}$ 8.3). Gels were stained with ethidium bromide at $0.5 \mu \mathrm{g} / \mathrm{ml}$ and differences in DNA fingerprint patterns were assessed visually.

Comparisons of DNA fingerprint patterns were performed by measurement of band positions of PCR products. The presence or absence of each band in each bacterial strain was converted into binary data ( 1 for presence and 0 for absence). These data then were used as an input file for the MIX parsimony program of PHYLIP (10) to generate a phylogenetic tree. In cases of multiple data sets, the sets were combined to generate a consensus tree using CONSENSE (9). Finally, all the trees were visualized using the TREEVIEW program (16). The reliability of the dendrogram was assessed by a bootstrap analysis with the SEQBOOT program (9). In all, 1,000 repeated samplings with replacement were made in each analysis. The frequencies with which each group was formed in repeated cycles of dendrogram construction were used as a measure of the relative reliability of the clusters of the strains.

DNA-DNA hybridization. Purification of genomic DNA was performed using the method of Brenner et al. (5). Briefly, the bacterial cells were lysed with $0.05 \mathrm{M}$ TE buffer containing $0.5 \%$ sodium dodecyl sulfate (SDS) and pronase at $50 \mu \mathrm{g} / \mathrm{ml}$, followed by phenol extraction. DNA from the aqueous phase then was precipitated with $95 \%$ ethanol and washed with $70 \%$ ethanol. The resulting crude DNA solution then was incubated overnight at $37^{\circ} \mathrm{C}$ with RNase at $50 \mu \mathrm{g} / \mathrm{ml}$ containing SDS $(0.5 \%$ final concentration) and pronase (50 $\mu \mathrm{g} / \mathrm{ml}$ final concentration). The DNA was extracted once with phenol and twice with chloroform, followed by three precipitations with ethoxyethanol. DNAs were sheared by sonication at $4^{\circ} \mathrm{C}(9)$.

The procedures used for the determination of DNA relatedness by hybridization in free solution by the hydroxyapatite method have been described previously (5). The DNAs were labeled enzymatically in vitro with $\left[{ }^{32} \mathrm{P}\right] \mathrm{dCTP}$ by nick translation. DNA-DNA hybridization experiments were performed at $60^{\circ} \mathrm{C}$ for optimal DNA reassociation and also at the stringent temperature of $75^{\circ} \mathrm{C}$. The percent divergence of hybrids was calculated as decrease of 
$1{ }^{\circ} \mathrm{C}$ in thermal stability of a heterologous DNA duplex, which correlates to approximately $1 \%$ unpaired bases within related DNA. The guidelines of Wayne et al. (23) were used in defining hybridization groups. These guidelines indicate that strains within the same species should have a DNA relatedness, as measured by relative binding ratio (RBR), of $\geq 70 \%$ and a divergence of $\leq 5 \%$. The experiments of DNA-DNA hybridization were performed twice.

\section{RESULTS}

rep-PCR. A total of 29 CYVD-associated $S$. marcescens strains, 16 CYVD-nonassociated $S$. marcescens strains, and 5 other Serratia type strains were tested by rep-PCR. Each reaction was repeated at least three times and only the repeatable banding patterns were used for phylogenetic analysis. The PCR products of all 29 CYVD-associated S. marcescens strains, regardless of the geographic location, plant host species, or collection date, showed a homogeneous pattern (data not shown). Five of these strains finally were selected to compare with other strains (Fig. 1A to $\mathrm{C}$, lanes 1 to 5 ) and to generate phylogenetic trees (Fig. 2). $S$. marcescens isolates from other ecological niches, as well as the type strains of different Serratia spp., showed a variety of patterns, all of which were different from those of CYVD isolates (Fig. 1A to C, lanes 6 to 24).

Distinguishable banding patterns were generated in all PCR primer combinations. For reactions using PGRS and BOX primers, the size of the amplicons ranged from 0.5 to $6 \mathrm{~kb}$. Two rice endophyte strains, R02-A (IRBG 502) and R03-A (IRBG 505), showed identical patterns using both PGRS and BOX primers. Two insect pathogenic strains, I06-A and I09-A, also were identical with each other. Two bands generated from PGRS PCR, with sizes of 1.2 and $1.4 \mathrm{~kb}$, respectively, were shared by all the $S$. marcescens strains. In BOX-primed PCR, one band of $0.6 \mathrm{~kb}$ was shared by all the $S$. marcescens strains. Twenty-seven bands were amplified using ERIC primers, and the size of amplified DNA ranged from 0.3 to $5 \mathrm{~kb}$. Although fewer bands were generated from ERIC primers, the banding patterns of $S$. marcescens appeared to be as diverse as those from BOX and PGRS reactions.

The banding patterns of BOX, PGRS, and ERIC PCR products each were scored separately as binary data. Phylogenetic trees were generated for each of the three rep-PCR reactions. The three

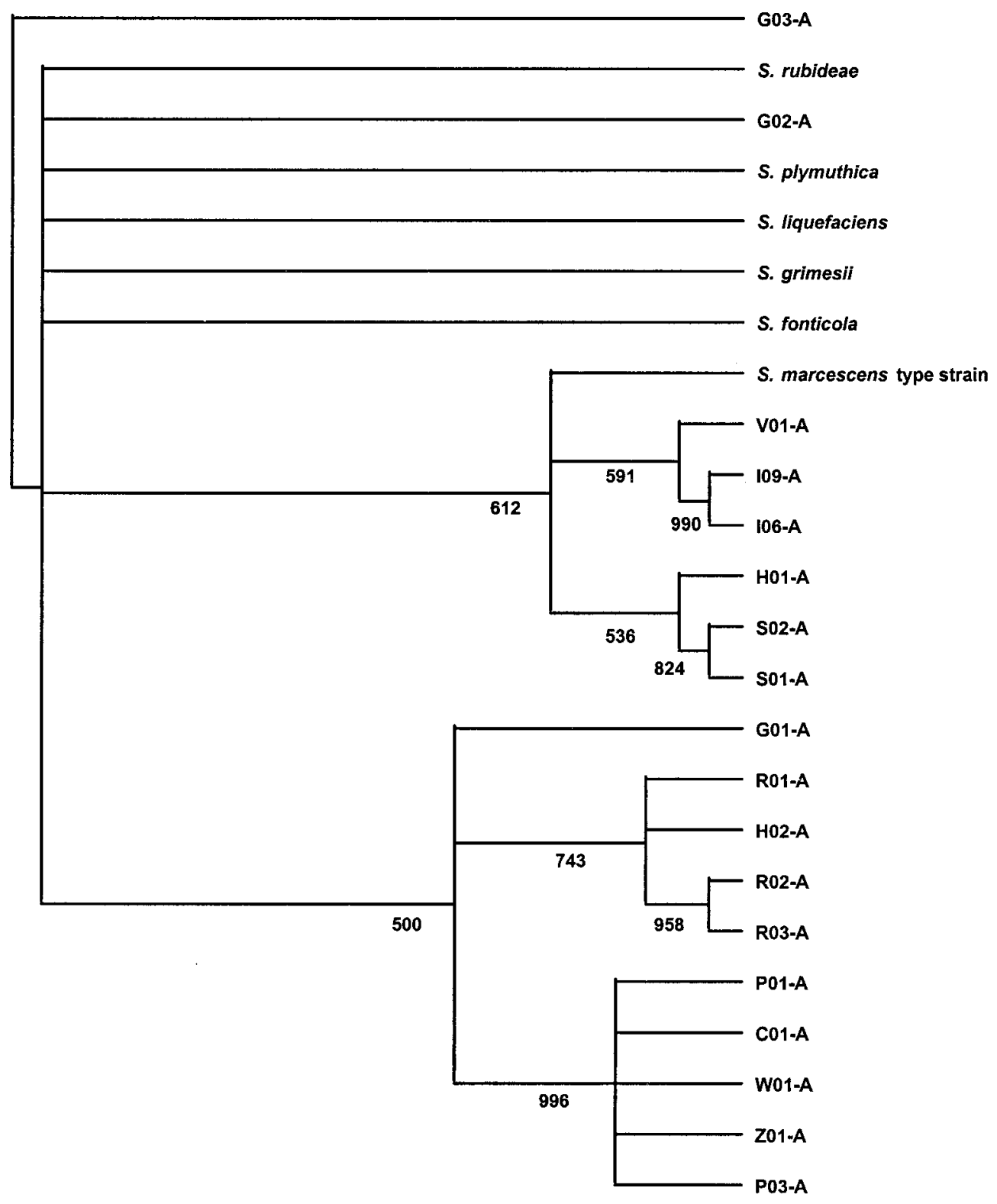

Fig. 2. Consensus phylogenetic tree of the relationships among Serratia spp. and strains, compiled from binary data based on the banding patterns of three different repetitive elements-based polymerase chain reaction sets. Branches with bootstrap values less than 500 were collapsed. 
trees were similar in that the CYVD strains grouped together within a large branch containing the $S$. marcescens type strain (data not shown). When the data from all three PCR reactions were combined, the consensus phylogenetic tree was similar to the trees generated from individual reactions, except that branches with low bootstrap value were collapsed. All the $S$. marcescens strains tested fell into two groups.

DNA-DNA hybridization. DNA-relatedness studies were conducted using labeled reference DNA from C01-A, the $S$. marcescens type strain, G03-A (JM-983), the S. proteamaculans type strain, and G02-A (JM-965), respectively (Table 2). As a representative CYVD strain, C01-A, from cantaloupe, was hybridized to all the strains listed in Table 2 at both 60 and $75^{\circ} \mathrm{C}$, while the other labeled reference strains were hybridized only at $60^{\circ} \mathrm{C}$ to a limited number of strains, as shown. At the optimal reassociation temperature $\left(60^{\circ} \mathrm{C}\right)$, labeled C01-A DNA showed an average RBR of $99 \%$ (range from 94 to $100 \%$ ) and $0.33 \%$ divergence (from 0.0 to $1.0 \%$ ) to other CYVD strains. At the same temperature, C01-A hybridized with the $S$. marcescens type strain with a $76 \%$ RBR and $4.5 \%$ divergence. In addition, C01-A DNA had an RBR of 73 to $90 \%$ relative to all the other $S$. marcescens reference strains, with an average percent divergence of 2.1 (range from 1.0 to $3.5 \%$ ). In contrast, the relatedness values between C01-A and type strains of other Serratia spp. were well below 70\%, and the percent divergences were 10.5 to $13.5 \%$. Labeled DNA from the $S$. marcescens type strain hybridized to unlabeled C01-A DNA with a $69 \%$ RBR, slightly lower than the $76 \%$ RBR obtained when labeled C01-A DNA reacted with the type strain. However, the percent divergences obtained from both reactions were $<5.0 \%$. According to the criteria of species definition (23), our data clearly illustrate that C01-A and other CYVD strains group together and belong to species $S$. marcescens. In more stringent hybridization reactions carried out at $75^{\circ} \mathrm{C}$, labeled C01-A DNA showed an average RBR of $72 \%$ (range from 62 to $88 \%$ ) to $S$. marcescens DNA from different niches, which reflects the reliability of results obtained at $60^{\circ} \mathrm{C}$.

\section{DISCUSSION}

As a PCR-based fingerprinting method, rep-PCR has the advantages of convenience and sensitivity. In our study, 29 CYVD strains showed $100 \%$ similarity by rep-PCR despite the fact that they were collected from different plant species, in different years, and at different geographic locations. This method clearly discriminated CYVD-associated strains from strains of $S$. marcescens not associated with CYVD.

Rep-PCR, based on repetitive elements such as ERIC, BOX, and PGRS, has been used to study the epidemiology of a wide array of microorganisms. These three families of unrelated repetitive DNA sequences vary in location throughout the chromosome and show different discriminatory ability depending on the species examined. In this study, ERIC PCR generated fewer bands than did BOX and PGRS, similar to the observation of Patton et al. (18) for $S$. marcescens but in contrast to a previous study by Liu et al. (12) using the same species. Nevertheless, the phylogenetic trees generated in our study from PCR patterns amplified by all

TABLE 2. DNA relatedness disclosed by DNA-DNA hybridization, with respect to strains of cucurbit yellow vine disease (CYVD)-associated and nonassociated strains of Serratia marcescens and other Serratia spp.

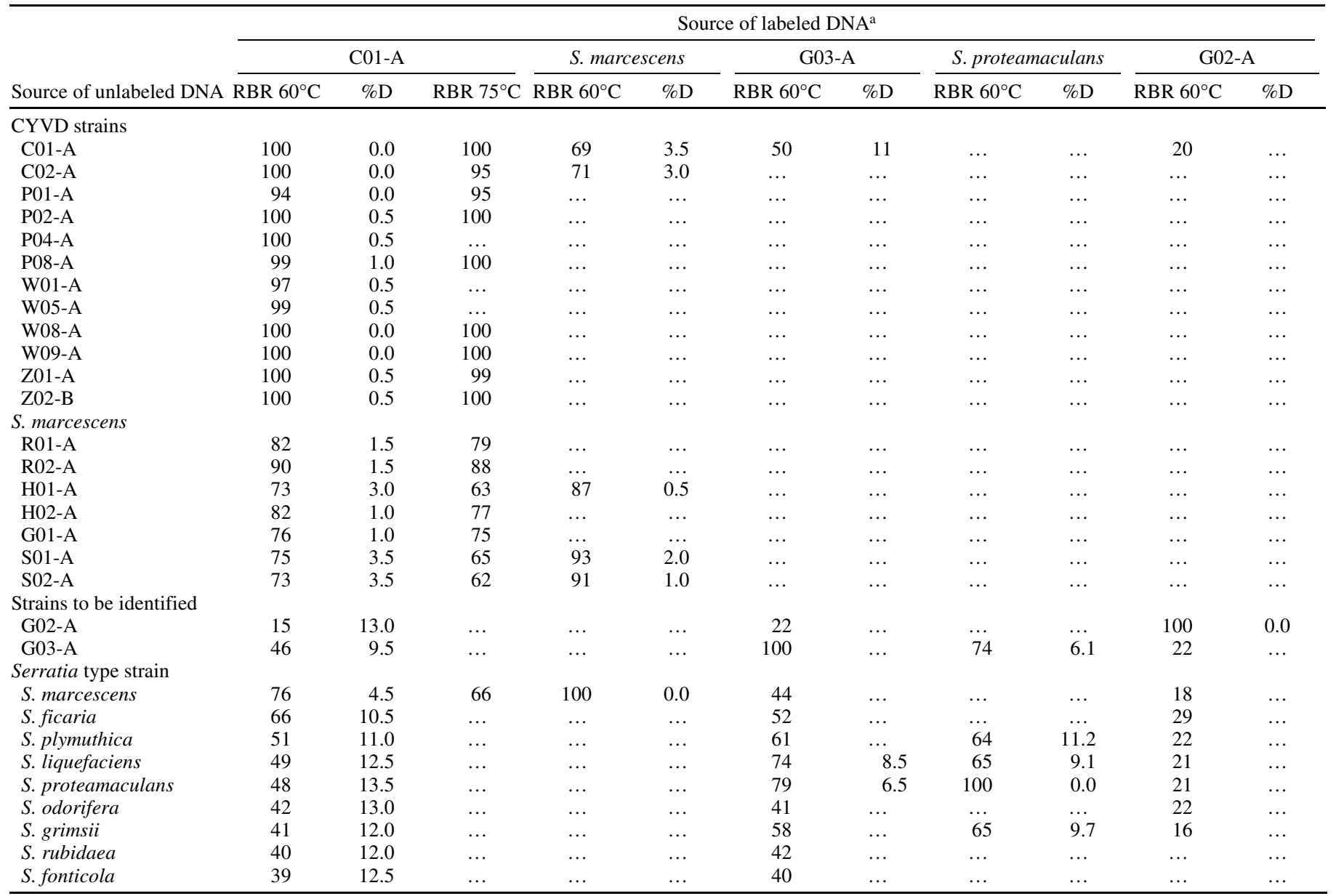

${ }^{a}$ Relative binding ratio (RBR) is determined by the equation (percent bound to hydroxylapatite in heterologous reactions)/(percent DNA bound in homologous reactions $) \times 1,000$. Percent divergence $(\% \mathrm{D})$ assumed that a $1{ }^{\circ} \mathrm{C}$ decrease in thermal stability of a heterologous DNA duplex compared with that of the homologous duplex was caused by $1 \%$ unpaired bases. 
three primer sets were very similar. The final consensus phylogenetic tree generated from rep-PCR banding patterns also was similar to the trees generated from $16 \mathrm{~S}$ rDNA and groE sequence analysis (19). All the CYVD strains were identical to each other and fell into a group containing CYVD nonassociated $S$. marcescens strains.

Results from the DNA-DNA hybridization study also illustrate that CYVD strains form a closely related group. As a reference strain of this group, C01-A was more than $70 \%$ related to the $S$. marcescens type strain, with a percent divergence of $<5.0$. This result supported the placement of CYVD strains in the species $S$. marcescens. In a previous study (19), the biological tests BIOLOG, Vitek, API-20E, and FAME indicated that the metabolic capabilities and fatty acid composition of the CYVD strains were quite different from those of CYVD nonassociated strains, including the $S$. marcescens type strain. The approximately 25 to $30 \%$ difference at the genome level might be responsible for these phenotypic differences.

The DNA relatedness between C01-A and other CYVD strains ranged from 94 to $100 \%$, as shown by DNA-DNA hybridization. This result is in contrast to the unanimous identity revealed in repPCR analysis. Considering the fact that, in rep-PCR, the amplicons may represent only a small portion of the genome, and bands with the same electrophoretic mobility were not compared for DNA sequence similarity, we believe that DNA-DNA hybridization is likely a more accurate measure than is rep-PCR of the genetic complementarities. Even the lowest relatedness measured among CYVD strains (94\% RBR between C01-A and P01-A) reflects the overall similarity among pathogenic strains, and the percent divergence of $0.0 \%$ suggests that the C01-A and P01-A similarity is actually even higher than suggested by the $94 \%$ RBR. This is in contrast to the results for $S$. marcescens clinical isolates, in which the rep-PCR banding patterns of different clinical isolates were quite diverse. This result suggests to us that CYVD strains of $S$. marcescens may have diverged from an ancestor much more recently than the human isolates have.

Rascoe et al. (19) found that strain G02-A (JM-965), which had been tentatively identified as $S$. marcescens, is significantly different from the $S$. marcescens type strain by $16 \mathrm{~S}$ rDNA and $g r o E$ analysis. In this study, the $15 \%$ RBR and $13.0 \%$ divergence clearly demonstrated that G02-A belongs to a species other than $S$. marcescens. Strain G03-A (JM-983), which had been tentatively designated as a strain of S. plymuthica, has an RBR of $>70 \%$ with $S$. proteamaculans, suggesting that it belongs to this species.

Both rep-PCR and DNA-DNA hybridization results showed that, among the CYVD nonassociated bacteria tested, the rice endophytic strains R02-A and R01-A were those most closely related to CYVD strains. Rice strain R03-A, which was not tested by DNA-DNA hybridization, was indistinguishable from R02-A based on BOX and PGRS PCR, a result in good agreement with data of Tan et al. (22), who characterized the rice endophytic strains more fully. Like the CYVD strains, all rice strains were nonpigmented and differed from the $S$. marcescens type strain in several key nutrient utilization characteristics. Preliminary results (B. D. Bruton, unpublished data) showed that none of the three rice strains were pathogenic to cucurbit plants. Comparing the rice endophytes with the phytopathogenic CYVD strains on the genetic level may be a starting point to the identification of virulence factors of CYVD strains.

In a separate study, Bextine et al. (3) demonstrated that the squash bug, Anasa tristis, is a vector of CYVD strains of $S$. marcescens. Insects of two other taxa (leafhoppers and mirids) also were able to transmit the CYVD pathogen under artificial conditions (1). However, in the work reported here, all strains isolated from field-collected insects were much more distantly related to CYVD strains than were the rice endophytes. These findings suggest the possibility that $S$. marcescens strains associated with plants may have followed two routes of evolutionary adaptation, one as a plant pathogen and the other as a harmless and possibly even beneficial endophyte. They also indicate that different strains of $S$. marcescens have different types of relationships with insects that harbor them, some as entomopathogens and others in a vector-host relationship.

Compared with the $S$. marcescens endophyte 90-166 and clinical isolate H01-A, CYVD strains lack 30 of the 95 metabolic capabilities in the BIOLOG test (19). Whether CYVD strains fail to produce those enzymes as a result of regulatory control of gene expression or by loss of genes due to genomic rearrangements during evolution, or both, is still unclear. Ochman (15) recently suggested that changes in genome repertoire, occurring through gene acquisition and deletion, are the major events underlying the emergence and evolution of bacterial pathogens and symbionts. In the future, analysis of $S$. marcescens from other niches that are more closely related to CYVD strains of $S$. marcescens might provide clues as to the origin and the evolutionary path of plantpathogenic strains.

\section{ACKNOWLEDGMENTS}

The work was funded by the Oklahoma State University Targeted Research Initiative Program, the Oklahoma Agricultural Experiment Station, Project 2092, and the U.S. Department of Agriculture Southern Regional IPM Program. We thank J. K. Ladha, J. Kloepper, A. H. Purcell, D. Adamson, S. P. Deng, and the American Type Culture Collection for providing bacterial cultures; and M. Berg and P. V. Alejandro for thoughtful review of the manuscript.

\section{LITERATURE CITED}

1. Al-Zadjali, T. 2002. Experimental vectors of Serratia marcescens, causal agent of cucurbit yellow vine disease. M.S. thesis. Oklahoma State University, Stillwater.

2. Ausubel, F. M., Brent, R., Kingston, R. E., Moore, D. D., Seidman, J. G., Smith, J. A., and Struhl, K. 1987. Current Protocols in Molecular Biology. John Wiley \& Sons, New York.

3. Bextine, B., Wayadande, A. Bruton, B. D., Pair, S. D., Mitchell, F., and Fletcher, J. 2001. Effect of insect exclusion on the incidence of yellow vine disease and of the associated bacterium in squash. Plant Dis. 85:875-878.

4. Bost, S. C., Mitchell, F. L., Melcher, U., Pair, S. D., Fletcher, J., Wayandande, A., and Bruton, B. D. 1999. Yellow vine of watermelon and pumpkin in Tennessee. Plant Dis. 83:587.

5. Brenner, D. J., McWhorter, A. C., Knutson, J. K., and Steigerwalt, A. G. 1982. Escherichia vulneris: A new species of Enterobacteriaceae associated with human wounds. J. Clin. Microbiol. 15:1133-1140.

6. Bruton, B. D., Mitchell, F., Fletcher, J., Pair, S. D., Wayadande, A., Melcher, U., Brady, J., Bextine, B., and Popham, T. W. 2003. Serratia marcescens, a phloem-colonizing, squash bug-transmitted bacterium: Causal agent of cucurbit yellow vine disease. Plant Dis. 87:937-944.

7. Bruton, B. D., Pair, S. D. Popham, T. W., and Cartwright, B. O. 1995. Occurrence of yellow vine, a new disease of squash and pumpkin, in relation to insect pests, mulches, and soil fumigation. Subtrop. Plant Sci. 47:53-58.

8. Bucher, G. E. 1960. Potential bacterial pathogens of insects and their characteristics. J. Insect Pathol. 2:172-195.

9. Falkow, S., and Citarella, R. V. 1965. Molecular homology of Fmerogenote DNA. J. Mol. Biol. 12:138-151.

10. Felsenstein, J. 1989. Phylogeny inference package. Cladistics 5:164-166.

11. Gillings, M., and Holley, M. 1997. Repetitive element PCR fingerprinting (rep-PCR) using enterobacterial repetitive intergenic consensus (ERIC) primers is not necessarily directed at ERIC elements. Lett. Appl. Microbiol. 25:17-21.

12. Liu, P. Y., Lau, Y. J., Hu, B. S., Shir, J. M., Cheung, M. H., Shi, Z. Y., and Tsai, W. S. 1994. Use of PCR to study epidemiology of Serratia marcescens isolates in nosocomial infection. J. Clin. Microbiol. 32: 1935-1938.

13. Lukezic, F. L., Hildebrand, D. C., Schroth, M. N., and Shinde, P. A. 1982. Association of Serratia marcescens with crown rot of alfalfa in Pennsylvania. Phytopathology 72:714-718.

14. Lupski, J. R., and Weinstock, G. M. 1992. Short, interspersed repetitive DNA sequences in prokaryotic genomes. J. Bacteriol. 174:4525-4529.

15. Ochman, H., and N. A. Moran. 2001. Genes lost and genes found: Evolution of bacterial pathogenesis and symbiosis. Science 292:10961099. 
16. Page, R. D. 1996. Treeview: An application to display phylogenetic trees on personal computers. Comput. Appl. Biosci. 12:357-358.

17. Pares, M. 1964. Action de Serratia marcescens dans le cycle biologique des metaux. Ann. Inst. Pasteur Lille 107:136-141.

18. Patton, T. G., Katz, S., Sobieski, R. J., and Crupper, S. S. 2001. Genotyping of clinical Serratia marcescens isolates: A comparison of PCR-based methods. FEMS Microbiol. Lett. 194:19-25.

19. Rascoe, J., Berg, M., Melcher, U., Mitchell, F. L., Bruton, B. D., Pair, S. D., and Fletcher, J. 2003. Identification, phylogenetic analysis, and biological characterization of Serratia marcescens strains causing cucurbit yellow vine disease. Phytopathology 93:1233-1239.

20. Sambrook, J. E., Fritsch, E. F., and Maniatis, T. 1989. Molecular Cloning: A Laboratory Manual. 2nd ed. Cold Spring Harbor Laboratory, Cold Spring Harbor, NY.

21. Sears, R. G., Ditterline, R. L., and Mathre, D. E. 1975. Crown and root rotting organisms affecting sainfoin (Onobrychis vicifolia) in Montana. Plant Dis. Rep. 59:423-426.
22. Tan, Z., Hurek, T., Gyaneshwar, P., Ladha, J. K., and ReinholdHurek, B. 2001. Novel endophytes of rice form a taxonomically distinct subgroup of Serratia marcescens. Syst. Appl. Microbiol. 24:245251.

23. Wayne, L. G., Brenner, D. J., Colwell, R. R., Grimont, P. D., Kandler, O., Krichevsky, M. I., and Moore, L. H. 1987. Report of the ad hoc committee on reconciliation of approaches to bacterial systematics. Int. J. Syst. Bacteriol. 37:463-464.

24. Wei, G., Kloepper, J. W., and Tuzun, S. 1996. Induced systemic resistance to cucumber diseases and increased plant growth by plant growthpromoting rhizobacteria under field conditions. Phytopathology 86:221224.

25. Whalen, T. A. 1970. Serratia marcescens: A pathogen. Science 168: 64.

26. Wick, R. L., Lernal, J., Fletcher, J., Mitchell, F., and Bruton, B. D. 2001. Detection of cucurbit yellow vine disease in squash and pumpkin in Massachusetts. Plant Dis. 85:1031. 